\title{
Effects of Light Intensity and Paclobutrazol on Growth and Interior Performance of Pachira aquatica Aubl.
}

\author{
Qiansheng Li, Min Deng, Jianjun Chen ${ }^{1}$, and Richard J. Henny \\ University of Florida, IFAS, Department of Environmental Horticulture and \\ Mid-Florida Research and Education Center, 2725 Binion Road, Apopka, FL \\ 32703
}

Additional index words. light acclimatization, light compensation point, money tree, ornamental foliage plants

\begin{abstract}
Pachira aquatica Aubl. has recently been introduced as an ornamental foliage plant and is widely used for interiorscaping. Its growth and use under low light conditions, however, have two problems: leaf abscission and accelerated internode elongation. This study was undertaken to determine if production light intensity and foliar application of paclobutrazol [ $\beta$-(4-chlorophenyl)methyl- $\alpha-(1,1-$ dimethylethyl)$1 H$ - 1,2,4- triazole-1-ethanol] improved plant growth and subsequent interior performance. Two-year-old $P$. aquatica trunks were planted in $15-\mathrm{cm}$ diameter plastic pots using a peat-based medium and were grown in a shaded greenhouse under three daily maximum photosynthetic photon flux densities $(P P F D)$ of 285,350 , and $550 \mu \mathrm{mol} \cdot \mathrm{m}^{-2} \cdot \mathrm{s}^{-1}$. Plant canopy heights, average widths, and internode lengths were recorded monthly over a 1-year production period. Two months after planting, the plant canopy was sprayed once with paclobutrazol solutions at concentrations of 0,50 , and $150 \mathrm{mg} \cdot \mathrm{L}^{-1}, \approx 15 \mathrm{~mL}$ per plant. Before the plants were placed indoors under a $P P F D$ of $18 \mu \mathrm{mol} \cdot \mathrm{m}^{-2} \cdot \mathrm{s}^{-1}$ for 6 months, net photosynthetic rates, quantum yield, and light saturation and compensation points were determined. Results showed that lowering production light levels did not significantly affect canopy height, width, or internode length but affected the photosynthetic light response curve and reduced the light compensation point. Foliar application of paclobutrazol reduced internode length, thereby resulting in plants with reduced canopy height and width and more compact growth form. Paclobutrazol application also reduced the light compensation point of plants grown under $550 \mu \mathrm{mol} \cdot \mathrm{m}^{-2} \cdot \mathrm{s}^{-1}$. Plants with the compact growth form did not grow substantially, dropped fewer leaflets, and thus maintained their aesthetic appearance after placement indoors for 6 months. These results indicated that the ornamental value and interior performance of $P$. aquatica plants can be significantly improved by producing them under a $P P F D$ range between 285 and $350 \mu \mathrm{mol} \cdot \mathrm{m}^{-2} \cdot \mathrm{s}^{-1}$ and foliar spraying of paclobutrazol once at a concentration between 50 and $150 \mathrm{mg} \cdot \mathrm{L}^{-1}$.
\end{abstract}

Pachira aquatica Aubl., a member of the family Bombacaceae, is a tropical wetland tree indigenous to Central and South America from southern Mexico to Guyana and northeastern Brazil (Robyns, 1964). It has shiny green palmate leaves with five to nine lanceolate leaflets and a smooth green stem with a distinctive swollen base. Flowers are showy and have long, narrow petals and hair-like yellowish orange stamens. In its native habitat, $P$. aquatica grows under full sun or partial shade and can reach $18 \mathrm{~m}$ in height. Seeds are consumed raw (tastes like peanuts) or as roasted beans with a flavor of chestnuts. Thus, $P$. aquatica is also known as Malabar chestnut or Guyana chestnut. Young leaves

Received for publication 17 Mar. 2009. Accepted for publication 29 Apr. 2009.

We thank Penang Nursery, Inc., Apopka, FL, for providing the Pachira aquatica plants used in this study and Russell D. Caldwell for critical reading of the manuscript.

${ }^{1}$ To whom reprint requests should be addressed; e-mail jjchen@ufl.edu. and flowers are also edible as a vegetable (Oliveira et al., 2000). Propagation of $P$. aquatica is by means of seeds or stem cuttings.

In addition to being a specialty food crop, $P$. aquatica has recently been introduced as a tropical ornamental foliage plant. Large trunks are planted singly in containers or small trees (four to six) are grown together and braided as potted foliage plants used for interiorscaping. Because of its swollen stem base and flexibility of the branch and stem, $P$. aquatica is also grown as bonsai or pseudo bonsai. In East Asia, P. aquatica is known as the money tree and is believed to bring financial fortune in business. As an indoor plant, $P$. aquatica has been shown to reduce volatile organic compounds (Song et al., 2007). The money tree is also becoming popular in the United States as a potted house plant or bonsai. However, there are two common problems associated with its growth and use under low light conditions, leaf abscission and accelerated internode elongation, which are similar to the responses of Ficus benjamina L. to low light levels (Chen et al., 2001; Fonteno and McWilliams, 1978). Thus far, there is no information available regarding cultural practices to control the two problems in $P$. aquatica.

Leaf abscission is a major factor influencing interior performance of many ornamental plants (Embry and Northnagel, 1994). To have a plant that is used to growing under full sun or partial shade to better adapt to interior low light environments, light acclimatization is required (Chen et al., 2005a; Conover and Poole, 1984). There are two methods of light acclimatization (Chen et al., $2005 a)$. One is to grow plants under relatively high light conditions to near-finished sizes and then provide plants with a reduced light level for 4 to 5 weeks or longer before shipping to market for interiorscaping. The other is to grow plants initially under reduced light levels until marketable sizes are reached. Light acclimatization improves the plant interior performance by lowering the light compensation point, thus reducing leaf abscission and maintaining the aesthetic values during interiorscape (Chen et al., 2005a; Fonteno and McWilliams, 1978; Reyes et al., 1996; Yeh and Wang, 2000).

Production of plants under reduced light levels, however, may modify some morphological traits such as increasing internode length, which may affect the plant's aesthetic appearance, especially of some woody ornamental plants like Ficus and Schefflera (Kubatsch et al., 2006). To reduce rapid internode elongation under a low light level, plant growth retardants have been used as a foliar spray or soil drench (Davis, 1987). Paclobutrazol [ $\beta$-(4-chlorophenyl)methyl- $\alpha$ (1,1-dimethylethyl)-1H-1,2,4-triazole-1-ethanol] has been shown to control the height of Caladium $\times$ hortulanum Bird., Codiaeum variegatum (L.) Blume, Schefflera actinophylla Endl., Euphorbia pulcherrima Wind., and Impatiens wallerana (L.) Hook. f. (Barrett et al., 1994) as well as F. benjamina (Barrett and Nell, 1983). Application of flurprimidol \{a-(methylethyl)-a-[4-(trifluoromethoxy)phenyl]-5-pyrimidinemethanol\} or ancymidol [a-cyclopropyl-a-(4-methoxyphenyl)-5pyrimidinemethanol] controlled the height of Geogenanthus undatus C. Koch \& Linden (Burton et al., 2007). In a preliminary study using different growth retardants, we found that a foliar spray of paclobutrazol reduced the internode elongation, thus controlling the height of $P$. aquatica.

This study was undertaken to evaluate the effects of light intensity and paclobutrazol application on growth and subsequent interior performance of $P$. aquatica. The objective was to determine if the combination of production light level and paclobutrazol application could reduce the internode elongation and leaf drop and improve $P$. aquatica's ornamental value as an indoor foliage plant.

\section{Materials and Methods}

Two-year-old $P$. aquatica rooted trunks (trunk diameter 3 to $4 \mathrm{~cm}$ and height $25 \mathrm{~cm}$ 
with one branch) were obtained from a commercial nursery in Apopka, FL, and planted in $15-\mathrm{cm}$ diameter plastic pots in June 2006 using a sphagnum peat-based medium (Vergro Container Mix A; Verlite Co., Tampa, FL) in which Canadian peat, vermiculite, and perlite were in a 3:1:1 ratio based on volume. Potted plants were grown in a shaded greenhouse under three daily maximum photosynthetic photon flux densities (PPFD) of 285, 350, and 550 $\mu \mathrm{mol} \cdot \mathrm{m}^{-2} \cdot \mathrm{s}^{-1}$, which resulted from the installation of shadecloth with three different densities (Chen et al., 2005a). Temperatures in the shaded greenhouse ranged from 20 to $32{ }^{\circ} \mathrm{C}$ and relative humidity varied from $50 \%$ to $100 \%$. All plants were fertilized with topdress application of a $15 \mathrm{~N}-7 \mathrm{P}_{2} \mathrm{O}_{5}-15 \mathrm{~K}_{2} \mathrm{O}$ controlled-release fertilizer, Multicote, with an 8-month longevity at a temperature of $21{ }^{\circ} \mathrm{C}$ (Haifa Chemicals Ltd., Haifa Bay, Israel) at a rate of $0.75 \mathrm{~g}$ nitrogen per pot. Plants were irrigated three to four times a week with a leaching fraction of 0.2 . Two months after planting, the plants had established their canopies with five to six palmate leaves. After recording canopy heights and average widths (means of the widest width and width perpendicular) and mean internode length (stem height divided by the number of nodes), plants grown under the three $P P F D$ were subjected to a one-time spray of paclobutrazol (Uniroyal Chemical Co., Middlebury, CT) solutions at rates of 0,50 , and 150 $\mathrm{mg} \cdot \mathrm{L}^{-1}$ of a.i., respectively. Approximately $15 \mathrm{~mL}$ of the solutions were sprayed per plant with the potting medium surface covered to keep paclobutrazol off the medium. The experiment was arranged in a split plot design with nine plants per treatment. Plants were grown in the shaded greenhouse for an additional 10 months, during which canopy heights and average widths were measured monthly. Mean internode lengths were recorded at the end of production.

Photosynthetic light response curves were measured in July 2007 using a Li-6400 portable photosynthesis meter (Li-COR Bio- science, Lincoln, NE) on the newest developed mature leaves of each treatment. The range of $P P F D$ was set at 5, 15, 25, 50, 100, 250,500 , and $750 \mu \mathrm{mol} \cdot \mathrm{m}^{-2} \cdot \mathrm{s}^{-1}$ using the Li6400-02B light source. The $\mathrm{CO}_{2}$ concentration was set at $380 \mu \mathrm{mol} \cdot \mathrm{mol}^{-1}$, the rate of air flow was maintained at $300 \mu \mathrm{mol} \cdot \mathrm{s}^{-1}$, and the leaf chamber $(2 \times 3 \mathrm{~cm})$ temperature was set at $28{ }^{\circ} \mathrm{C}$. Curve-fitting software (Sigma Plot for Windows 10.0; Systat Software, Richmond, CA.) was used to analyze the light responses using a three-component exponential function equation $\mathrm{A}=\mathrm{a}\left(1-\mathrm{e}^{-\mathrm{bx}}\right)+\mathrm{c}$ (Watling et al., 2000), where $\mathrm{A}=$ net photosynthetic rate and $\mathrm{x}=P P F D ; \mathrm{a}, \mathrm{b}$, and $\mathrm{c}$ were parameters estimated by the nonlinear regression. Light-saturated photosynthesis rate $\mathrm{A}_{\text {sat }}$ was calculated as a $+c$, and the quantum yield of photosynthesis $\left(\mathrm{A}_{\mathrm{qe}}\right)$ was calculated as the initial slope at $\mathrm{A}=0$ [calculated as $\mathrm{b}(\mathrm{a}+\mathrm{c})$ ]. The light compensation point was determined by solving this equation for $P P F D$ at A of $0 \mu \mathrm{mol} \cdot \mathrm{m}^{-2} \cdot \mathrm{s}^{-1}$. The light saturation point was determined by the $P P F D$ at which A was $99 \%$ of the light-saturated net photosynthesis (Burton et al., 2007; Peek and Russek-Cohen, 2002; Watling et al., 2000).

To measure the anatomical characteristics, recently matured leaves of plants produced from different treatments were taken in July 2007 and fixed in FAA (formalin:glacial acetic acid:70\% ethanol at 5:5:90 by volume). After dehydration through an alcoholxylol series, the samples were embedded in Paraplast with a 56 to $58{ }^{\circ} \mathrm{C}$ melting point, sectioned at $8 \mu \mathrm{m}$, and stained with SafraninFast green and mounted on Permount (Fisher Scientific, Inc., Pittsburgh, PA). Sections were observed with a Nikon OPTIPHOT microscope (Nikon Nippon Kogaku K.K., Tokyo, Japan) and photographed using a Canon S3 IS digital camera (Cannon U.S.A., Inc., Lake Success, NY).

After photosynthesis measurement and leaf anatomical examination, plants from five replications were placed in interior evaluation rooms with a $P P F D$ of $18 \mu \mathrm{mol} \cdot \mathrm{m}^{-2} \cdot \mathrm{s}^{-1}$ provided by white fluorescent lamps. All interior rooms were lit $12 \mathrm{~h}$ daily with a temperature set at $24{ }^{\circ} \mathrm{C}$ and relative humidity $\approx 50 \%$. Plants were monitored weekly and watered as needed for 6 months. The number of dropped leaflets, plant height and width, and mean internode length were recorded monthly. The interior evaluation experiment was arranged in a randomized block design. There were five rooms as five blocks; each room held nine plants, one per treatment.

Data were analyzed using the SAS General Linear Model procedure (SAS Institute, 1996). All data were subjected to analysis of variance. When significant differences occurred, means were separated by Duncan's new multiple range test at $P=0.05$.

\section{Results and Discussion}

Effects on plant canopy. All plants initially had similar canopy heights (36.8 to 40.8 $\mathrm{cm})$, average widths $(48.2 \mathrm{~cm}$ to $52.9 \mathrm{~cm})$, and five to six palmate leaves before the foliar spray of paclobutrazol. Canopy heights and widths, internode lengths, and the percentage of canopy height and width increases at the end of production were not significantly different among plants grown under the three light regimes without paclobutrazol treatment (Table 1), althrough the net photosynthetic rate of plants grown under 550 $\mu \mathrm{mol} \cdot \mathrm{m}^{-2} \cdot \mathrm{s}^{-1}$ was higher with $\mathrm{A}_{\max }$ of 4.7 compared with 4.2 and 3.3 at 350 and 285 $\mu \mathrm{mol} \cdot \mathrm{m}^{-2} \cdot \mathrm{s}^{-1}$, respectively (Table 2 ). The discrepancy between the higher net photosynthetic rate and nonsignificant increase in the measured growth parameters could be attributed to the higher photosynthesisenhancing plant dry matter accumulation such as increased leaf thickness and mechanical strength but not affecting plant form such as canopy heights and widths. As shown in Figure 1, the leaves of plants grown under $P P F D$ of $550 \mu \mathrm{mol} \cdot \mathrm{m}^{-2} \cdot \mathrm{s}^{-1}$ were thicker than those grown under $285 \mu \mathrm{mol} \cdot \mathrm{m}^{-2} \cdot \mathrm{s}^{-1}$.

Canopy height, internode length, and percentage of canopy height increase were significantly reduced 10 months after the plants

Table 1. Effects of different light intensities and concentrations of paclobutrazol as a one-time foliar spray on Pachira aquatica plant growth in a shaded greenhouse for 1 year.

\begin{tabular}{|c|c|c|c|c|c|c|}
\hline \multirow{2}{*}{$\begin{array}{l}\text { Light intensity } \\
\left(\mu \mathrm{mol} \cdot \mathrm{m}^{-2} \cdot \mathrm{s}^{-1}\right)\end{array}$} & \multirow{2}{*}{$\begin{array}{l}\text { Paclobutrazol concn } \\
\left(\mathrm{mg} \cdot \mathrm{L}^{-1}\right)\end{array}$} & \multicolumn{2}{|c|}{10 months after paclobutrazol application } & \multirow{2}{*}{$\begin{array}{l}\text { Mean internode } \\
\text { length }(\mathrm{cm})^{\mathrm{y}}\end{array}$} & \multicolumn{2}{|c|}{ Percentage of increase $^{z}$} \\
\hline & & Canopy ht (cm) & Canopy width $(\mathrm{cm})$ & & Canopy ht & Canopy width \\
\hline 285 & 50 & $60.4 \mathrm{~b}$ & $86.1 \mathrm{ab}$ & $1.2 \mathrm{~b}$ & $50.2 \mathrm{~b}$ & $62.8 \mathrm{abc}$ \\
\hline 350 & 50 & $55.6 \mathrm{~b}$ & $77.8 \mathrm{abc}$ & $0.9 \mathrm{~b}$ & $36.9 \mathrm{~b}$ & $44.9 \mathrm{abc}$ \\
\hline 350 & 150 & $45.4 \mathrm{~b}$ & $66.4 \mathrm{~cd}$ & $0.8 \mathrm{~b}$ & $15.8 \mathrm{~b}$ & $26.5 \mathrm{~d}$ \\
\hline 550 & 0 & $82.8 \mathrm{a}$ & $87.4 \mathrm{ab}$ & $11.1 \mathrm{a}$ & $106.0 \mathrm{a}$ & $81.3 \mathrm{a}$ \\
\hline \multicolumn{7}{|l|}{ Significance $^{\mathrm{w}}$} \\
\hline Light & & NS & NS & NS & NS & NS \\
\hline Paclobutrazol & & ** & ** & ** & ** & ** \\
\hline Interaction & & NS & NS & NS & NS & NS \\
\hline
\end{tabular}

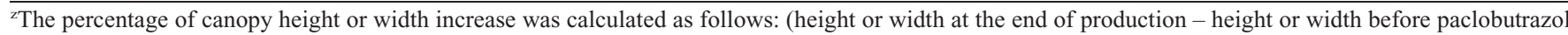
application)/height or width before paclobutrazol application.

${ }^{y}$ The mean internode length was the stem height divided by the number of nodes.

${ }^{\mathrm{x}}$ Means within column followed by different letters are significantly different by Duncan's new multiple range test at $P=0.05$.

${ }^{\mathrm{w}_{\mathrm{NS}}}$ indicates nonsignificant; $* *$ significant at $P=0.01(\mathrm{n}=9)$. 
Table 2. Maximum net photosynthesis rate $\left(\mathrm{A}_{\max }\right)$, quantum yield $\left(\mathrm{A}_{\mathrm{qe}}\right)$, light compensation point (LCP), and light saturation point (LSP) of Pachira aquatica plants grown under different light intensities and treated with different rates of paclobutrazol.

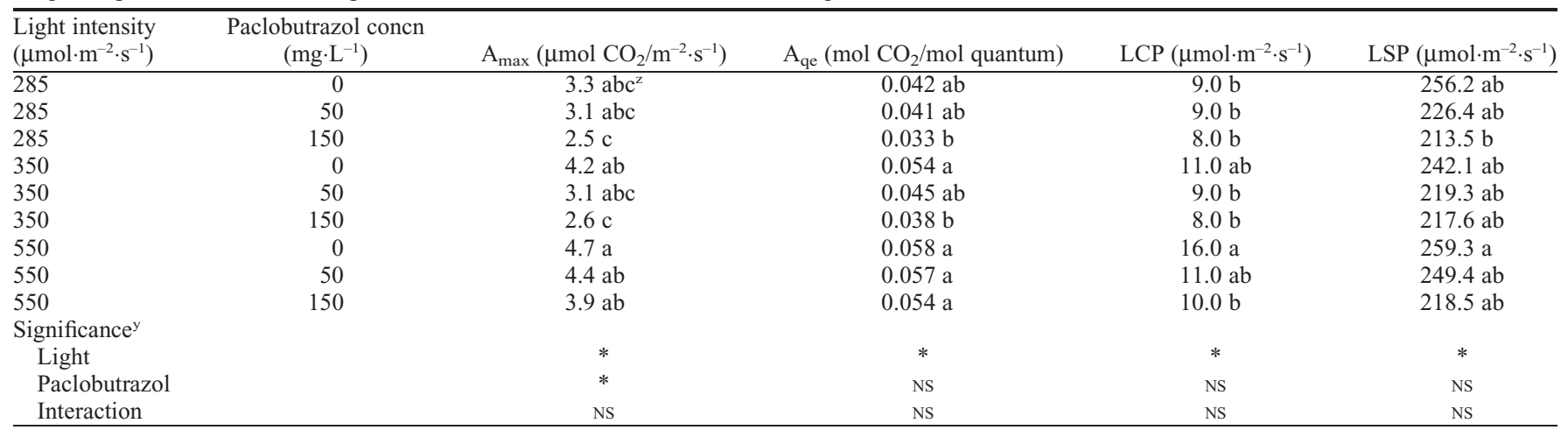

${ }^{2}$ Means within column followed by different letters are significantly different by Duncan's new multiple range test at $P=0.05$.

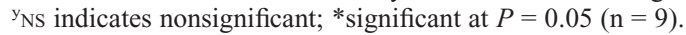

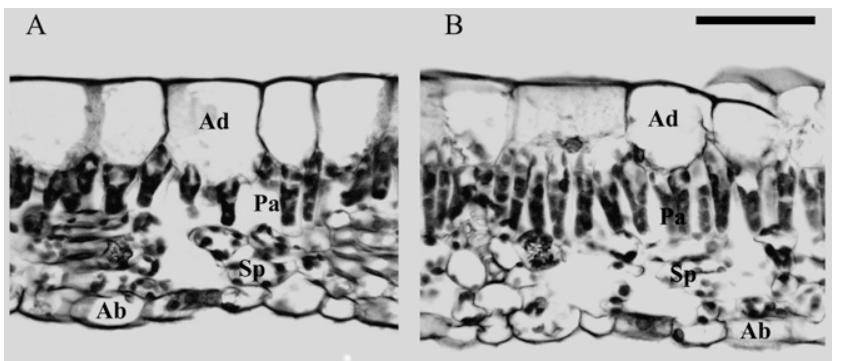

Fig. 1. The leaf transverse sections of Pachira aquatica grown under daily maximum photosynthetic photon flux densities $(P P F D)$ of $285 \mu \mathrm{mol} \cdot \mathrm{m}^{-2} \cdot \mathrm{s}^{-1}$ (A) and $550 \mu \mathrm{mol} \cdot \mathrm{m}^{-2} \cdot \mathrm{s}^{-1}($ B) . More elongated palisade mesophyll cells occurred in leaves of plants grown under $P P F D$ of $550 \mu \mathrm{mol} \cdot \mathrm{m}^{-2} \cdot \mathrm{s}^{-1}$ (B) compared with the leaves produced under $285 \mu \mathrm{mol} \cdot \mathrm{m}^{-2} \cdot \mathrm{s}^{-1}$ (A). The palisade cells were vertically aligned more tightly in the leaves of plants grown under $550 \mu \mathrm{mol} \cdot \mathrm{m}^{-2} \cdot \mathrm{s}^{-1}$ than in the leaves of plants grown under $285 \mu \mathrm{mol} \cdot \mathrm{m}^{-2} \cdot \mathrm{s}^{-1}$. Ad $=$ adaxial epidermal cells; $\mathrm{Pa}=$ palisade parenchyma; $\mathrm{Sp}=$ spongy parenchyma; $\mathrm{Ab}=$ abaxial epidermal cuticle cells. $\mathrm{Bar}=0.1 \mathrm{~mm}$.

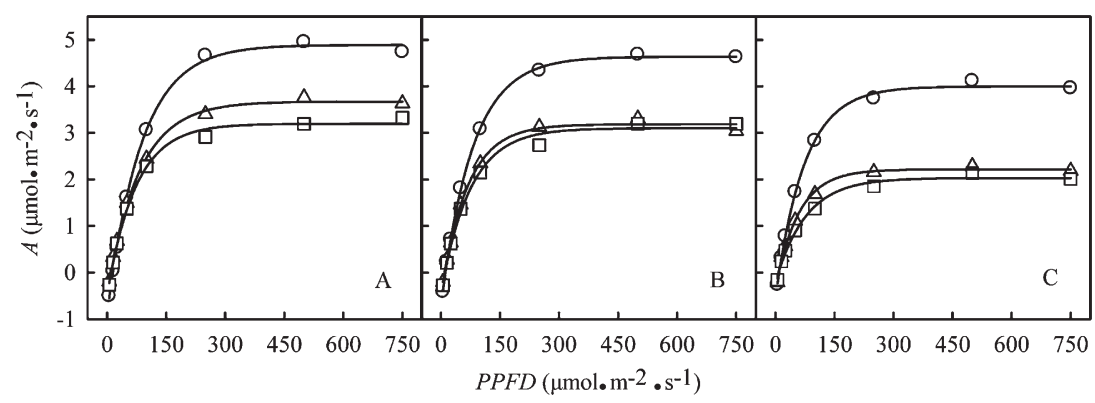

Fig. 2. Photosynthetic -light response curves of Pachira aquatica plants one year after growing in a shaded greenhouse under three daily maximum photosynthetic photon flux densities of $550(\mathrm{o}), 350(\Delta)$, and $285(\square) \mu \mathrm{mol} \cdot \mathrm{m}^{-2} \cdot \mathrm{s}^{-1}$ with a foliar spray of paclobutrazol at concentrations of $0(\mathbf{A}), 50(\mathbf{B})$, and 150 (C) $\mathrm{mg} \cdot \mathrm{L}^{-1}$.

were treated with paclobutrazol regardless of the production light levels, but these parameters did not significantly differ between plants treated with the two paclobutrazol concentrations (Table 1). The average internode lengths of plants treated with paclobutrazol ranged from 0.8 to $1.2 \mathrm{~cm}$ compared with 10.3 to $11.1 \mathrm{~cm}$ of the control plants. As a result, canopy heights increased only $14.3 \%$ to $50.8 \%$ for plants treated with paclobutrazol but $95.7 \%$ to $106.0 \%$ for control plants. Canopy widths and percentages of canopy width increase were significantly reduced by paclobutrazol treatment at $150 \mathrm{mg} / \mathrm{mL}$ but not at $50 \mathrm{mg} / \mathrm{mL}$. Paclobutrazol application in reduction of internode length was also reported in Plectranthus australis $\mathrm{R}$. Br., Zebrina pendula Schnizl., and F. benjamina (Davis, 1987) as well as Gynura aurantiaca (Blume) DC (Chen et al., 2002) and other floriculture crops (Barrett et al., 1994). Paclobutrazol is an effective inhibitor that blocks gibberellin biosysnthesis by inhibiting kaurene oxidase, an enzyme-converting kaurene to kaurenoic acid (Wang et al., 1986). When gibberellin biosysnthesis is blocked, cell division still occurs, but the new cells do not elongate, which results in shoots with the same numbers of leaves but compressed internodes (Chaney, 2003). As a consequence, $P$. aquatica treated with paclobutrazol showed a compact appearance, thereby increasing its ornamental value.

Effects on photosynthesis. The net photosynthetic rates (A) of $P$. aquatica increased rapidly as $P P F D$ increased from 0 to 150 $\mu \mathrm{mol} \cdot \mathrm{m}^{-2} \cdot \mathrm{s}^{-1}$ and reached their saturation at a $P P F D$ range of 213 to $259 \mu \mathrm{mol} \cdot \mathrm{m}^{-2} \cdot \mathrm{s}^{-1}$ (Fig. $2)$. In general, plants grown under higher $P P F D$ have high light saturation points because of the higher level of enzymes for carboxylation and electron transport (Callan and Kennedy, 1995). In the present study, light saturation points of plants grown under the three PPFD regardless of paclobutrazol treatments did not significantly differ except for plants grown under $285 \mu \mathrm{mol} \cdot \mathrm{m}^{-2} \cdot \mathrm{s}^{-1}$ and treated by paclobutrazol at $150 \mathrm{mg} \cdot \mathrm{L}^{-1}$ that were significantly lower than plants grown under $500 \mu \mathrm{mol} \cdot \mathrm{m}^{-2} \cdot \mathrm{s}^{-1}$ without paclobutrazol treatment (Table 2). These results generally concurred with those reported by Seemann (1989) in which light saturation points of soybean (Glycine max L.) grown under 250 to $500 \mu \mathrm{mol} \cdot \mathrm{m}^{-2} \cdot \mathrm{s}^{-1}$ and 1000 to $1500 \mu \mathrm{mol} \cdot \mathrm{m}^{-2} \cdot \mathrm{s}^{-1}$ were not significantly different. The explanation was that plants grown under 1000 to $1500 \mu \mathrm{mol} \cdot \mathrm{m}^{-2} \cdot \mathrm{s}^{-1}$ had higher Rubisco than those grown under 250 to $500 \mu \mathrm{mol} \cdot \mathrm{m}^{-2} \cdot \mathrm{s}^{-1}$. As a result, photosynthesis per unit of Rubisco for plants grown under the two light regimes were almost equal and thus similar light saturation points (Seemann, 1989).

The quantum yield $\left(\mathrm{A}_{\mathrm{qe}}\right)$ ranged from 0.033 to $0.058 \mathrm{~mol} \mathrm{CO}_{2} / \mathrm{mol}$ quantum, which was similar to the range from 0.037 to 0.069 mol $\mathrm{CO}_{2} / \mathrm{mol}$ quantum estimated in Begonia semperflorens-cultorum Hort. (Nemali and van Iersel, 2004). Plants grown under PPFD of 285 and $350 \mu \mathrm{mol} \cdot \mathrm{m}^{-2} \cdot \mathrm{s}^{-1}$ and treated by paclobutrazol at $150 \mathrm{mg} \cdot \mathrm{L}^{-1}$ had lower quantum yields than those grown under the $P P F D$ of $350 \mu \mathrm{mol} \cdot \mathrm{m}^{-2} \cdot \mathrm{s}^{-1}$ without paclobutrazol treatment or those grown under $550 \mu \mathrm{mol}$. $\mathrm{m}^{-2} \cdot \mathrm{s}^{-1}$ irrespective of paclobutrazol treatment (Table 2). Correspondingly, $A_{\max }$ of 
those plants with the reduced quantum yield significantly decreased. However, conflicting results exist regarding paclobutrazol effects on photosynthesis. Vu and Yelenosky (1992) reported that net photosynthesis of Citrus sinensis (L.) Osbeck was reduced by paclobutrazol application, whereas Jaleel et al. (2007) reported that photosynthesis of Catharanthus roseus (L.) G. Don. was enhanced by paclobutrazol. The results from the present study were in agreement with those reported by $\mathrm{Vu}$ and Yelenosky (1992). The reduced net photosynthetic rate in P. aquatica was correlated with the reduction in the quantum yield (Table 2). The quantum yield of $\mathrm{CO}_{2}$ assimilation has been widely used for evaluating the efficiency of photosynthesis at low PPFD (Ehleringer and Bjorkman, 1977).

Light compensation points of $P$. aquatica grown under $P P F D$ of $285 \mu \mathrm{mol} \cdot \mathrm{m}^{-2} \cdot \mathrm{s}^{-1}$ ranged from 8.0 to $9.0 \mu \mathrm{mol} \cdot \mathrm{m}^{-2} \cdot \mathrm{s}^{-1}$, which was not significantly affected by paclobutrazol application (Table 2). However, light compensation points of plants grown under 350 and $550 \mu \mathrm{mol} \cdot \mathrm{m}^{-2} \cdot \mathrm{s}^{-1}$ decreased from 11.0 to 8.0 and from 16.0 to $10.0 \mu \mathrm{mol} \cdot \mathrm{m}^{-2} \cdot \mathrm{s}^{-1}$, respectively. The light compensation point reduction appeared to relate to the reduction of quantum yield and maximum net photosynthetic rate (Table 2).

Leaf anatomical differences. Microscopic observations showed more elongated palisade mesophyll cells in leaves of $P$. aquatica grown under $P P F D$ of $550 \mu \mathrm{mol} \cdot \mathrm{m}^{-2} \cdot \mathrm{s}^{-1}$ (Fig. 1B) compared with the leaves produced under $285 \mu \mathrm{mol} \cdot \mathrm{m}^{-2} \cdot \mathrm{s}^{-1}$ (Fig. 1A) or under $350 \mu \mathrm{mol} \cdot \mathrm{m}^{-2} \cdot \mathrm{s}^{-1}$ regardless of paclobutrazol application. The elongation of palisade cells resulted in slightly thicker leaves when plants were grown under $550 \mu \mathrm{mol} \cdot \mathrm{m}^{-2} \cdot \mathrm{s}^{-1}$. The palisade cells in the leaves of plants grown under $550 \mu \mathrm{mol} \cdot \mathrm{m}^{-2} \cdot \mathrm{s}^{-1}$ were vertically and more tightly aligned compared with the loosely arrayed palisade cells in the leaves of plants grown under $285 \mu \mathrm{mol} \cdot \mathrm{m}^{-2} \cdot \mathrm{s}^{-1}$. The tight alignment resulted in the reduction of intercellular spaces with a larger number of palisade cells per unit area (Fig. 1). Thus, net photosynthetic rates of plants grown under $P P F D$ of $550 \mu \mathrm{mol} \cdot \mathrm{m}^{-2} \cdot \mathrm{s}^{-1}$ were higher than those grown under the low $P P F D$. The palisade cell orientation was similar to that observed in F. benjamina (Fails et al., 1982) in which palisade cells were tightly aligned along radial walls in leaves of plants grown under high $P P F D$ compared with a loose alignment in leaves of plants grown under low PPFD. However, unlike $F$. benjamina in which there were multiple layers of palisade cells, leaves of $P$. aquatica had only one layer of palisade cells.

Effects on interior performance. Plant growth after placement indoors for 6 months depended on treatment. Canopy height increase ranged from $0.2 \%$ to $6.5 \%$ for plants treated with paclobutrazol and $8.0 \%$ to $11.1 \%$ for those without paclobutrazol treatment (Table 3). Canopy width increase varied from $0.1 \%$ to $6.8 \%$ regardless of treatment, but such an increase was not significant. The results showed that residual effects of paclobutrazol remained in plants for 16 months. Karaguzel and Ortacesme (2002) reported that internode lengths of Bougainvillea glabra Choisy 'Sanderiana' treated with a foliar spray of paclobutrazol could reach the internode lengths of control plants in only $120 \mathrm{~d}$. The prolonged effect may indicate that $P$. aquatica is more sensitive to paclobutrazol than $B$. glabra because plant species differences in paclobutrazol sensitivity have been widely documented (Barrett et al., 1994; Wang and Blessington, 1990).

There was little change in mean internode length and canopy height of plants treated by paclobutrazol at $150 \mathrm{mg} \cdot \mathrm{L}^{-1}$ irrespective of production light levels. Canopy heights, mean internode lengths, and the percentage of canopy height increases were also significantly decreased by paclobutrazol treatment at $50 \mathrm{mg} \cdot \mathrm{L}^{-1}$. Leaflet drop occurred 3 weeks after placement indoors. Production $P P F D$ played a more important role in preventing leaflet drop than paclobutrazol treatment. Regardless of paclobutrazol treatment, the number of leaflets dropped ranged from 10 to 23 for plants produced under 550 $\mu \mathrm{mol} \cdot \mathrm{m}^{-2} \cdot \mathrm{s}^{-1}$ compared with one to five and six to 12 for those produced under 285 and $350 \mu \mathrm{mol} \cdot \mathrm{m}^{-2} \cdot \mathrm{s}^{-1}$, respectively. The reduced leaflet drop is probably because the plants grown under low PPFD had low light compensation points, thus allowing them to better and more quickly adapt to interior low light conditions. Similar results were also reported in Chamaedorea elegans Mart. (Reyes et al., 1996), F. benjamina (Chen et al., 2005b; Fonteno and McWilliams, 1978; Pass and Hartley, 1979), Hedera helix L. (Yeh and Hsu, 2004), and Leea coccina L. and Leea rubra L. (Sarracino et al., 1992).

Paclobutrazol treatment also reduced leaflet drop; such reduction was more pronounced for plants produced under $P P F D$ of $550 \mu \mathrm{mol} \cdot \mathrm{m}^{-2} \cdot \mathrm{s}^{-1}$ than those produced under $285 \mu \mathrm{mol} \cdot \mathrm{m}^{-2} \cdot \mathrm{s}^{-1}$. Reduced leaf drop was reported in $F$. benjamina during a simulated shipping and interiorscape when plants were treated with ancymidol (Peterson and Blessington, 1982). The interior performance of $F$. benjamina, Radermachera sincica (Hance) Hemsl., and Epipremnum aureum (Linden \& Andre) Bunt. was improved by paclobutrazol application (Barrett and Nell, 1983; Poole and Conover, 1992). However, there has been no report on paclobutrazol application in the reduction of leaf drop. The leaf drop reduction in $P$. aquatica could also be attributed to the fact that paclobutrazol treatment decreased the light compensation points of plants grown under $550 \mu \mathrm{mol}$. $\mathrm{m}^{-2} \cdot \mathrm{s}^{-1}$ (Table 2).

In conclusion, $P$. aquatica responded to decreasing production $P P F D$ and paclobutrazol application rates by reducing net photosynthetic rates, lowering light compensation points, and reducing internode lengths and canopy heights and widths. Plants with the

Table 3. Canopy heights and widths, percentage of canopy height and width increase, and leaf drop of Pachira aquatica plants after placing in interior conditions for 6 months. ${ }^{2}$

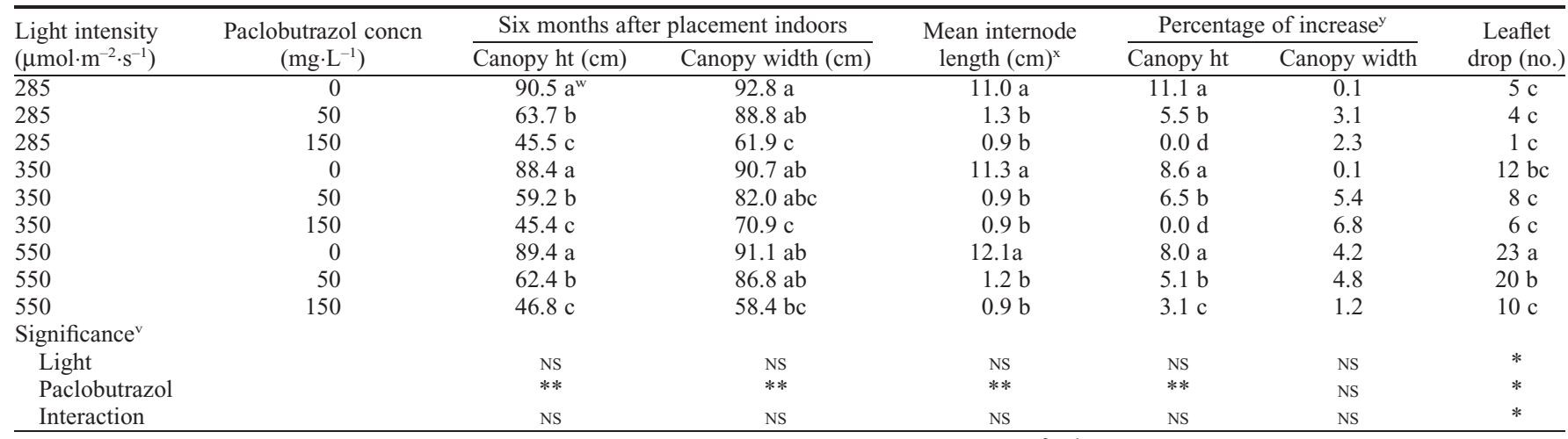

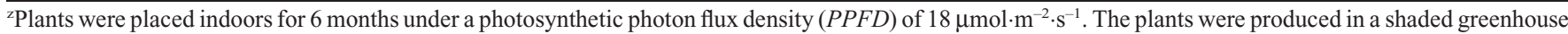
under three $P P F D$ for 1 year and treated by a one-time foliar application of three rates of paclobutrazol 2 months after potting.

${ }^{y}$ The percentage of canopy height or width increase was calculated as follows: (height or width at the end of indoor evaluation - height or width at the end of production)/height or width at the end of production.

${ }^{x}$ The mean internode length was the stem height divided by the number of nodes.

${ }^{\text {w} M e a n s ~ w i t h i n ~ c o l u m n ~ f o l l o w e d ~ b y ~ d i f f e r e n t ~ l e t t e r s ~ a r e ~ s i g n i f i c a n t l y ~ d i f f e r e n t ~ b y ~ D u n c a n ' s ~ n e w ~ m u l t i p l e ~ r a n g e ~ t e s t ~ a t ~} P=0.05$.

${ }^{v} \mathrm{NS}$ indicates nonsignificant; **significant at $P=0.01$ and *significant at $P=0.05(\mathrm{n}=5)$. 
compact growth form grew slowly and dropped few leaflets, thus maintaining their aesthetic appearance after placement indoors for 6 months. Based on the results presented in this study, it is suggested that production of $P$. aquatica under a $P P F D$ range between 285 and $350 \mu \mathrm{mol} \cdot \mathrm{m}^{-2} \cdot \mathrm{s}^{-1}$ with one-time foliar spraying of paclobutrazol at a concentration between 50 and $150 \mathrm{mg} \cdot \mathrm{L}^{-1}$ after canopy establishment can result in plants with a compact appearance and prolonged interior performance.

\section{Literature Cited}

Barrett, J.E., C.A. Bartuska, and T.A. Nell. 1994. Comparison of paclobutrazol drench and spike applications for height control of potted floriculture crops. HortScience 29:180-182.

Barrett, J.E. and T.A. Nell. 1983. Ficus benjamina response to growth retardants. Proc. Fla. State Hort. Soc. 96:264-265.

Burton, A.L., S.V. Pennisi, and M.W. van Iersel. 2007. Morphology and postharvest performance of Geogenanthus undatus C. Koch \& Linden 'Inca' after application of ancymidol or flurprimidol. HortScience 42:544-549.

Callan, E.J. and C.W. Kennedy. 1995. Intercropping stokes aster: Effects of shade on photosynthesis and plant morphology. Crop Sci. 35:1110-1115.

Chaney, W.R. 2003. Tree growth retardants: Arborists discovering new uses for an old tool. Tree Care Industry 14:54-59.

Chen, J., R.J. Henny, and R.D. Caldwell. 2002. Ethephon suppresses flowering of purple passion (Gynura aurantiaca). J. Environ. Hort. 20:228-231.

Chen, J., R.J. Henny, D.B. McConnell, and T.A. Nell. 2001. Cultivar differences in interior performances of acclimatized foliage plants. Acta Hort. 543:135-140.

Chen, J., D.B. McConnell, D.J. Norman, and R.J. Henny. 2005a. The foliage plant industry. Hort. Rev. (Amer. Soc. Hort. Sci.) 31:45-110.

Chen, J., Q. Wang, D.B. McConnell, and R.J. Henny. 2005b. Responses of tropical foliage plants to interior low light conditions. Acta Hort. 669:51-56.

Conover, C.A. and R.T. Poole. 1984. Acclimatization of indoor foliage plants. Hort. Rev. (Amer. Soc. Hort. Sci.) 6:119-147.
Davis, T.D. 1987. Interior performance of three foliage plant species treated with paclobutrazol. Appl. Agri. Res. 2:120-123.

Ehleringer, J. and O. Bjorkman. 1977. Quantum yield for $\mathrm{CO}_{2}$ uptake in $\mathrm{C}_{3}$ and $\mathrm{C}_{4}$ plants. Plant Physiol. 59:86-90.

Embry, J.L. and E.A. Northnagel. 1994. Leaf senescence of postproduction poinsettia in low-light stress. J. Amer. Soc. Hort. Sci. 119:1006-1013

Fails, B.S., A.J. Lewis, and J.A. Barden. 1982. Light acclimatization potential of Ficus benjamina. J. Amer. Soc. Hort. Sci. 107:762-766.

Fonteno, W.C. and E.L. McWilliams. 1978. Light compensation point and acclimatization of four tropical foliage plants. J. Amer. Soc. Hort. Sci. 103:52-56.

Jaleel, C.A., P. Manivannan, B. Sankar, A. Kishorekumar, S. Sankari, and R. Panneerselvam. 2007. Paclobutrazol enhances photosynthesis and ajmalicine production in Catharanthus roseus. Process Biochem. 42:1566-1570.

Karaguzel, O. and V. Ortacesme. 2002. Influence of paclobutrazol on the growth and flowering of Bougainvillea glabra 'Sanderiana'. Akdeniz Üniversitesi Ziraat Fakültesi Dergisi 15:79-84.

Kubatsch, A., H. Grüneberg, and C. Ulrichs. 2006. Acclimatization of Ficus benjamina and Schefflera arboricola to indoor temperatures and low light intensities. Acta Hort. 711:133-138.

Nemali, K.S. and M.W. van Iersel. 2004. Acclimation of wax begonia to light intensity: Changes in photosynthesis, respiration, and chlorophyll concentration. J. Amer. Soc. Hort. Sci. 129:745-751.

Oliveira, J.T.A., I.M. Vasconcelos, L.C.N.M Bezerra, S.B. Silveira, A.C.O. Monteiro, and R.A. Moreira. 2000. Composition and nutritional properties of seeds from Pachira aquatica Aubl, Sterculia striata St Hil et Naud and Terminalia catappa Linn. Food Chem. 70:185-191.

Pass, R.G. and D.E. Hartley. 1979. Net photosynthesis of three foliage plants under low irradiation levels. J. Amer. Soc. Hort. Sci. 104:745-748.

Peek, M.S. and E. Russek-Cohen. 2002. Physiological response curve analysis using nonlinear mixed models. Oecologia 132:175-180.

Peterson, J.C. and T.M. Blessington. 1982. Postharvest effects of ancymidol on Ficus benjamina L. HortScience 17:612-614.
Poole, R.T. and C.A. Conover. 1992. Paclobutrazol and indoor light intensity influence water use of some foliage plants. Proc. Fla. State Hort. Soc. 105:178-180.

Reyes, T., T.A. Nell, J.E. Barrett, and C.A. Conover. 1996. Irradiance level and fertilizer rate affect acclimatization of Chamaedorea elegans Mart. HortScience 31:839-841.

Robyns, A. 1964. Flora of Panama. Part VI. Family 116. Bombacaceae. Ann. Missouri Bot. Gard. 51:37-68.

Sarracino, J.M., R. Merritt, and C.K. Chin. 1992. Light acclimatization potential of Leea coccinai and Leea rubra grown under low light flux. HortScience 27:404-406.

SAS Institute. 1996. SAS user's guide. SAS Institute, Cary, NC.

Seemann, J.R. 1989. Light adaptation/acclimation of photosynthesis and the regulation of ribulose-1,5-bisphosphate carboxylase activity in sun and shade plants. Plant Physiol. 91:379386.

Song, J.E., Y.S. Kim, and J.Y. Sohn. 2007. The impact of plants on the reduction of volatile organic compounds in a small space. J. Physiol. Anthropol. 26:599-603.

Vu, J.C.V. and G. Yelenosky. 1992. Growth and photosynthesis of sweet orange plants treated with paclobutrazol. J. Plant Growth Regul. 11:85-89.

Wang, S.Y., T. Sun, and M. Faust. 1986. Translocation of paclobutrazol, a gibberellin biosynthesis inhibitor, in apple seedlings. Plant Physiol. 82:11-14.

Wang, Y.T. and T.M. Blessington. 1990. Growth of four tropical foliage species treated with paclobutrazol or uniconazole. HortScience 25:202204.

Watling, J.R., M.C. Press, and W.P. Quick. 2000. Elevated $\mathrm{CO}_{2}$ induces biochemical and ultrastructural changes in leaves of the $\mathrm{C}_{4}$ cereal sorghum. Plant Physiol. 123:1143-1152.

Yeh, D.M. and P.Y. Hsu. 2004. Differential growth and photosynthetic response of selected cultivars of English ivy to irradiance. J. Hort. Sci. Biotechnol. 79:633-637.

Yeh, D.M. and H.M. Wang. 2000. Effects of irradiance on growth, net photosynthesis and indoor performance of the shade-adapted plant, maidenhair fern. J. Hort. Sci. Biotechnol. 75:293-298. 